\title{
Pengaruh Aminoethoxyvinylglycine (Avg), Plastic Wrapping Dan Suhu Simpan Terhadap Masa Simpan Dan Mutu Buah Jambu Biji (Psidium Guajava L.) 'Mutiara'
}

\section{Effects Of Aminoethoxyvinylglycine (Avg), Plastic Wrapping, And Storage Temperatures On The Shelf-Life And The Qualities Of 'Mutiara' Guava Fruits}

\author{
Soesiladi E. Widodo ${ }^{1}$, Kuswanta F. Hidayat ${ }^{1}$, Zulferiyenni ${ }^{2}$, Sherly I. \\ Annisa $^{1}$ \\ ${ }^{1}$ Jurusan Agroteknologi, Fakultas Pertanian, Universitas Lampung \\ ${ }^{2}$ Teknologi Hasil Pertanian, Fakultas Pertanian, Universitas Lampung \\ Jln. Prof. Soemantri Brodjonegoro, No. 1, Bandar Lampung 35145. \\ E-mail: sestiwidodo@gmail.com
}

\begin{abstract}
The research was aimmed at studying the effects of (1) single application AVGs, plastic wrappings, and storage temperatures, (2) interactions among AVGs and plastic wrappings, AVGs and storage temperatures, and plastic wrappings and storage temperatures, and (3) interactions among AVGs, plastic wrappings, and storage temperatures in extending fruit self-life and maintain qualities of 'Mutiara'guava fruits. The research was arranged in a completely randomized design in $2 \times 2 \times 2$ factorial with three replications. The first factor was AVGs (with 1,25 ppm and without $A V G$ ), the second factor was plastic wrappings (without and with one layer of plastic wrapping), and the third factor was storage temperature (a cold temperature of $21,53{ }^{\circ} \mathrm{C}$ and a room temprature of $26,57^{\circ} \mathrm{C}$ ). The result showed that (1) the application of AVG 1,25 ppm did not significantly affect fruit self-life, fruit firmness, fruit weight loss, 'Brix, acid contens, and sweetness of 'Mutiara'guava' fruits, (2) storage at cold temprature of $21,53{ }^{\circ} \mathrm{C}$ did not significantly affect fruit selflife, fruit firmness, fruit weight loss, ${ }^{\circ}$ Brix, acid contens, and sweetness of 'Mutiara'guava' fruits, (3) the application of plastic wrapping was able to extend fruit self-life by 17 days longer than without plastic wrapping and supressed fruit weight loss of 'Mutiara'guava, but accelerated softening and not able to maintain ${ }^{\circ} B r i x$, and also did not significantly affect acid contens, and sweetness of 'Mutiara'guava fruits, (4) there were no interaction effects among AVGs with plastic wrappings, AVGs with cold tempratures, and plastic wrappings with cold tempratures on self-life, fruit firmness, fruit weight loss, ${ }^{\circ}$ Brix, acid contens, and sweetness of 'Mutiara'guava fruits, and (5) there were no interaction effects among AVGs, plastic wrappings, and cold temperatures on fruit self-life, fruit firmness, fruit weight loss, ${ }^{\circ}$ Brix, acid contens, and sweetness of 'Mutiara' guava fruits.
\end{abstract}

Keywords: 'Mutiara'guava, AVG, plastic wrapping, ripening, temperature

Diterima: 01 Februari 2016, disetujui 24 April 2016 



\section{PENDAHULUAN}

Jambu biji tergolong buah yang bersifat klimakterik yang ditandai dengan peningkatan respirasi dan produksi etilen yang tinggi selama proses pemasakan. Peningkatan tersebut menyebabkan masa simpan buah tidak bertahan lama. Dengan demikian, perlu dilakukan penanganan untuk menurunkan laju respirasi dan produksi etilen sehingga dapat menghambat proses pemasakan.

Penanggulangan pascapanen perlu dilakukan dengan memperpanjang masa simpan dan mempertahankan mutu buah jambubiji. Dalam memperpanjang masa simpan, dapat dilakukan aplikasi aminoethoxyvinylglycine (AVG) untuk menghentikan produksi etilen. AVG adalah zat alami pengatur pertumbuhan yang kompetitif menghambat ACC sintase atau membatasi laju enzim pada biosintesis etilen (Cline, 2006), dengan memblok atau menonaktifkan gen pengkode atau enzim yang memproduksi etilen sehingga proses pemasakan terhambat (Capitani et al., 2002). Pengaplikasian AVG diharapkan mampu memperpanjang masa simpan dan mempertahankan mutu jambu biji.

Penanganan juga dapat dilakukan dengan pengemasan danpenyimpanan pada suhu dingin. Pengemasan dengan plastic wrapping mampu memperpanjang masa simpan dan mempertahankan mutu buah. Penelitian sebelumnya oleh Widodo et al. (2013) menunjukkan bahwa pelapisan dengan plastic wrapping secara nyata meningkatkan masa simpan 4,40 hari dan mempertahankan mutu jambu biji 'Mutiara' dibandingkan dengan tanpa plastic wrapping. Plastic wrapping diharapkan mampu menghambat respirasi dan transpirasi yang tinggi. Penyimpanan pada suhu dingin merupakan salah satu cara dalam menekan laju respirasi dan proses metabolisme lainnya yang dapat menurunkan masa simpan dan mutu buah. Selama penyimpanan suhu rendah $\left(10^{\circ} \mathrm{C}\right)$, laju respirasi lebih rendah dalam sel buah dibandingkan dengan suhu tinggi $\left(20^{\circ} \mathrm{C}\right)$ yangdapat merusak jaringan buah (Ruzaina et al., 2013).

Penelitian ini bertujuan untuk mengetahui pengaruh (1) aplikasi tunggal AVG, plastic wrapping, dan suhu dingin, (2) interak siantara (AVG) dan plastic wrapping, AVG dan suhu dingin, dan plastic wrapping dan suhu dingin, dan (3) interaksi antara AVG, plastic wrapping, dan suhu dingin dalam memperpanjang masa simpan dan mempertahankan mutu buah jambu biji 'Mutiara'.

\section{METODE}

Penelitian ini dilaksanakan di Laboratorium Pascapanen Hortikultura, Jurusan Agroteknologi, Fakultas Pertanian, Universitas Lampung pada bulan September sampai Oktober 2014. Bahan buah pada penelitian adalah jambu biji 'Mutiara' yang diperoleh dari PT Nusantara Tropical Farm (PT NTF), Kecamatan Way Jepara, Kabupaten Lampung Timur. Buah disortir berdasarkan ukuran dan kemasakan yang seragam. Bahan lain yang digunakan adalah aminoethoxyvinylglycine (AVG), plastic wrapping, aquades, air, $0,1 \mathrm{~N} \mathrm{NaOH}$, dan fenolptalin. Alat-alat yang digunakan adalah timbangan, penetrometer, refraktrometer-tangan 'Atago', centrifius 'Heratus Sepatech', erlemeyer, gelas ukur, labu ukur, gelas beaker, biuret, pipet gondok, pipet tetes, blender, pisau, timbangan, piring styrofoam, lemari es, AC, humidifier, dan thermohygrometer.

Penelitian disusun dalam rancangan teracak sempurna (rts) secara faktorial $2 \times 2 \times 2$ dengan tiga ulangan, masing-masing terdiri atas satu buah jambu biji. Faktor pertama adalah avg, yaitu dengan 1,25 ppm $\left(\mathrm{a}_{1}\right)$ dan tanpa avg $\left(\mathrm{a}_{0}\right)$, faktor kedua adalah plastic wrapping, yaitu dengan plastic wrapping $\left(\mathrm{p}_{1}\right)$ dan tanpa plastic wrapping $\left(\mathrm{p}_{0}\right)$, dan faktor ketiga adalah suhu simpan, yaitu suhu dingin $21,53^{\circ} \mathrm{C}$ $\left(\mathrm{t}_{1}\right)$ dan suhu kamar $26,87^{\circ} \mathrm{c}\left(\mathrm{t}_{0}\right)$. Perlakuan avg menggunakan $5 \mathrm{mg} / 41(1,25 \mathrm{ppm})$, dengan cara perendaman selama 10 menit. Seluruh data dianalisisdengananalisis ragam.analisis data dilanjutkan dengan uji beda nyata terkecil (bnt) pada taraf nyata 5\% (sas system for windows v6.12). 
Soesiladi E. Widodo Dkk, Pengaruh Aminoethoxyvinylglycine (Avg), Plastic Wrapping dan ....

\section{HASIL DAN PEMBAHASAN}

Berdasarkan Tabel 1, hasil penelitian menunjukkan bahwa aplikasi AVG 1,25 ppm ( $\left.\mathrm{A}_{1}\right)$ tidak berpengaruh nyata terhadap masa simpan buah jambu biji 'Mutiara'. Hal ini diduga karena perlakuan AVG 1,25 ppm yang digunakan masih rendah. Hasil penelitian Tarabih (2014) menunjukkan bahwa perlakuan AVG $30 \mathrm{ppm}$ pada buah pir 'Le Conte' yang disimpan pada suhu dingin mampu menghambat biosintesis etilen sehingga dapat menunda pemasakan dan memperpanjang masa simpan buah dibandingkan tanpa AVG. Hal yang sama ditunjukkan pada penelitian Toan et al. (2009) bahwa aplikasi AVG 142,5 ppm mampu memperpanjang masa simpan pisang 'Cavendish' selama 43,6 hari. Tetapi, penggunaan AVG dengan konsentrasi tinggi dianggap kurang ekonomis untuk penanggulangan pascapanen buah.

Tabel 1. Pengaruh AVG, plastic wrapping, dan suhu simpan terhadap masa simpan, kekerasan, dan susut bobot buah jambu biji 'Mutiara'

\begin{tabular}{|c|c|c|c|c|}
\hline & Perlakuan & $\begin{array}{l}\text { Masa Simpan* } \\
\text { (hari) }\end{array}$ & $\begin{array}{c}\text { Kekerasan Buah* } \\
\left(\mathrm{kg} / \mathrm{cm}^{2}\right)\end{array}$ & $\begin{array}{c}\text { Susut Bobot* } \\
(\%)\end{array}$ \\
\hline \multicolumn{5}{|l|}{ AVG } \\
\hline Tanpa & $\left(\mathrm{A}_{0}\right)$ & $14,58 \mathrm{a}$ & $14,33 \mathrm{a}$ & 27,16 a \\
\hline $1,25 \mathrm{ppm}$ & $\left(\mathrm{A}_{1}\right)$ & $16,75 \mathrm{a}$ & 14,47 a & 27,39 a \\
\hline BNT (5\%) & & 4,54 & 1,80 & 4,32 \\
\hline \multicolumn{5}{|c|}{ Plastic Wrapping } \\
\hline Tanpa & $\left(\mathrm{P}_{0}\right)$ & $7,25 \mathrm{~b}$ & $15,62 \mathrm{a}$ & 36,05 a \\
\hline 1 Lapis & $\left(\mathrm{P}_{1}\right)$ & $24,08 \mathrm{a}$ & $13,18 \mathrm{~b}$ & $18,50 \mathrm{~b}$ \\
\hline BNT $(5 \%)$ & & 4,54 & 1,80 & 4,32 \\
\hline \multicolumn{5}{|c|}{ Suhu Simpan } \\
\hline Kamar & $\left(\mathrm{T}_{0}\right)$ & $15,92 \mathrm{a}$ & $14,62 \mathrm{a}$ & $26,21 \mathrm{a}$ \\
\hline Dingin & $\left(\mathrm{T}_{1}\right)$ & $15,42 \mathrm{a}$ & $14,18 \mathrm{a}$ & $28,34 \mathrm{a}$ \\
\hline BNT (5\%) & & 4,54 & 1,80 & 4,32 \\
\hline \multicolumn{5}{|c|}{ AVGxPlastic Wrapping } \\
\hline $\mathrm{A}_{0} \mathrm{P}_{0}$ & & $7,17 \mathrm{~b}$ & $16,26 \mathrm{a}$ & $35,06 \mathrm{a}$ \\
\hline $\mathrm{A}_{0} \mathrm{P}_{1}$ & & $22,00 \mathrm{a}$ & $12,40 \mathrm{~b}$ & $19,25 \mathrm{~b}$ \\
\hline $\mathrm{A}_{1} \mathrm{P}_{0}$ & & $7,33 \mathrm{~b}$ & 14,98 a & $37,04 \mathrm{a}$ \\
\hline $\mathrm{A}_{1} \mathrm{P}_{1}$ & & $26,17 \mathrm{a}$ & $13,96 \mathrm{ab}$ & $17,74 \mathrm{~b}$ \\
\hline BNT $(5 \%)$ & & 5,86 & 2,43 & 5,81 \\
\hline \multicolumn{5}{|c|}{ AVG x Suhu Simpan } \\
\hline $\mathrm{A}_{0} \mathrm{~T}_{0}$ & & $14,50 \mathrm{a}$ & $14,34 \mathrm{a}$ & 24,90 a \\
\hline $\mathrm{A}_{0} \mathrm{~T}_{1}$ & & 14,67 a & $14,31 \mathrm{a}$ & $29,41 \mathrm{a}$ \\
\hline $\mathrm{A}_{1} \mathrm{~T}_{0}$ & & $17,33 \mathrm{a}$ & $14,90 \mathrm{a}$ & $27,52 \mathrm{a}$ \\
\hline $\mathrm{A}_{1} \mathrm{~T}_{1}$ & & $16,17 \mathrm{a}$ & $14,04 \mathrm{a}$ & $27,27 \mathrm{a}$ \\
\hline BNT (5\%) & & 12,61 & 3,03 & 12,83 \\
\hline \multicolumn{5}{|c|}{ Plastic Wrapping xSuhu Simpan } \\
\hline $\mathrm{P}_{0} \mathrm{~T}_{0}$ & & $8,50 \mathrm{~b}$ & $15,31 \mathrm{a}$ & 34,69 a \\
\hline $\mathrm{P}_{0} \mathrm{~T}_{1}$ & & $6,00 \mathrm{~b}$ & $15,93 \mathrm{a}$ & $37,41 \mathrm{a}$ \\
\hline $\mathrm{P}_{1} \mathrm{~T}_{0}$ & & $23,33 \mathrm{a}$ & $13,93 \mathrm{ab}$ & $17,72 \mathrm{~b}$ \\
\hline $\mathrm{P}_{1} \mathrm{~T}_{1}$ & & $24,83 \mathrm{a}$ & $12,43 \mathrm{~b}$ & $19,27 \mathrm{~b}$ \\
\hline BNT $(5 \%)$ & & 6,02 & 2,49 & 5,74 \\
\hline
\end{tabular}


Lanjutan Tabel 1

\begin{tabular}{lrll}
\hline AVG x Plastic Wrapping x Suhu Simpan & & & \\
$\mathrm{A}_{0} \mathrm{P}_{0} \mathrm{~T}_{0}$ & $7,67 \mathrm{~b}$ & $15,39 \mathrm{ab}$ & $32,18 \mathrm{a}$ \\
$\mathrm{A}_{1} \mathrm{P}_{0} \mathrm{~T}_{0}$ & $9,33 \mathrm{~b}$ & $15,22 \mathrm{ab}$ & $37,21 \mathrm{a}$ \\
$\mathrm{A}_{0} \mathrm{P}_{1} \mathrm{~T}_{0}$ & $21,33 \mathrm{a}$ & $13,29 \mathrm{bc}$ & $17,62 \mathrm{~b}$ \\
$\mathrm{~A}_{1} \mathrm{P}_{1} \mathrm{~T}_{0}$ & $25,33 \mathrm{a}$ & $14,57 \mathrm{abc}$ & $17,83 \mathrm{~b}$ \\
$\mathrm{~A}_{0} \mathrm{P}_{0} \mathrm{~T}_{1}$ & $6,67 \mathrm{~b}$ & $17,12 \mathrm{a}$ & $37,95 \mathrm{a}$ \\
$\mathrm{A}_{1} \mathrm{P}_{0} \mathrm{~T}_{1}$ & $5,33 \mathrm{~b}$ & $14,73 \mathrm{abc}$ & $36,88 \mathrm{a}$ \\
$\mathrm{A}_{0} \mathrm{P}_{1} \mathrm{~T}_{1}$ & $22,67 \mathrm{a}$ & $11,51 \mathrm{c}$ & $20,88 \mathrm{~b}$ \\
$\mathrm{~A}_{1} \mathrm{P}_{1} \mathrm{~T}_{1}$ & $13,35 \mathrm{bc}$ & $17,66 \mathrm{~b}$ \\
\hline $\mathrm{BNT}(5 \%)$ & $27,00 \mathrm{a}$ & 3,60 & 8,64 \\
\hline
\end{tabular}

*Nilai sejalur yang diikuti dengan huruf yang sama tidak berbeda nyata menurut uji BNT 5\%, tingkat kekerasan pada 0 hari simpan adalah $14,49 \mathrm{~kg} / \mathrm{cm}^{2}$.

Perlakuan 1 lapis plastic wrapping $\left(\mathrm{P}_{1}\right)$ secara nyata mampu memperpanjang masa simpan buah jambu biji 'Mutiara' 17 hari lebih lama dibandingkan tanpa plastic wrapping $\left(\mathrm{P}_{0}\right)$ (Tabel 1). Plastic wrapping dapat membatasi ketersediaan $\mathrm{O}_{2}$ sehingga respirasi menjadi terhambat. Kemasan plastik Low Density Polyethylen (LDPE) mampu menekan jumlah $\mathrm{O}_{2}$, perembesan $\mathrm{CO}_{2}$, dan tingkat pertukaran gas antara di dalam dan di luar ruangan buah (Jacomino et al., 2001). Dengan demikian, tingkat pertukaran gas yang rendah menyebabkan pemasakan menjadi tertunda. Hal ini memperkuat penelitian sebelumnya oleh Widodo et al., (2013) bahwa pengemasan dengan plastic wrapping mampu memperpanjang masa simpan buah jambu biji 'Mutiara'4,40 hari lebih lama dibandingkan tanpa plastic wrapping.

Laju respirasi sangat dipengaruhi oleh suhu. Pada dasarnya, suhu dingin akan menekan laju respirasi sehingga memperpanjang masa simpan buah. Hasil penelitian menunjukkan bahwa perlakuan buah yang disimpan pada suhu dingin $21,53{ }^{\circ} \mathrm{C} \quad\left(\mathrm{T}_{1}\right)$ tidak berbeda nyata dalam memperpanjang masa simpan buah jambu biji 'Mutiara' dengan perlakuan suhu kamar $26,87{ }^{\circ} \mathrm{C}\left(\mathrm{T}_{0}\right)$ (Tabel 1). Hal ini diduga bahwa suhu $21,53{ }^{\circ} \mathrm{C}$ tidak efektif untuk penyimpanan suhu dingin pada buah jambu biji sehingga diperlukan suhu lebih rendah dari $21^{\circ} \mathrm{C}$. Bron et al.(2005) mengemukakan bahwa suhu $11^{\circ} \mathrm{C}$ mampu menekan laju respirasi dibandingkan suhu $21{ }^{\circ} \mathrm{C}$. Laju respirasi yang rendah mampu menunda pemasakan buah.

Pada kombinasi dua perlakuan secara umum tidak myata dalammemperpanjang masa simpan buah jambu biji 'Mutiara' (Tabel 1). Tetapi, pada perlakuan yang terdapat plastic wrapping,yaitu plastic wrapping dan tanpa AVG $\left(\mathrm{A}_{0} \mathrm{P}_{1}\right)$,plastic wrapping dan $\mathrm{AVG}\left(\mathrm{A}_{1} \mathrm{P}_{1}\right)$, dan plastic wrapping dan suhu simpan $\left(\mathrm{P}_{1} \mathrm{~T}_{0}\right.$ dan $\left.\mathrm{P}_{1} \mathrm{~T}_{1}\right)$ mampu memperpanjang masa simpan buah dibandingkan kombinasi tanpa plastic wrapping. Tidak terdapat interaksi antara dua kombinasi perlakuan, hanya saja dipengaruhi oleh perlakuan tunggal plastic wrapping.

Berdasarkan Tabel 1, kombinasi tiga perlakuan secara umum tidak berbeda nyata terhadap masa simpan buah jambu biji 'Mutiara'. Tetapi, kombinasi perlakuan yang terdapat plastic wrappingyaitu perlakuan plastic wrapping yang dikombinasikan dengan AVG atau tanpa AVG pada suhu dingin atau suhu kamar $\left(\mathrm{A}_{0} \mathrm{P}_{1} \mathrm{~T}_{0}, \mathrm{~A}_{1} \mathrm{P}_{1} \mathrm{~T}_{0}, \mathrm{~A}_{0} \mathrm{P}_{1} \mathrm{~T}_{1}\right.$, dan $\left.\mathrm{A}_{1} \mathrm{P}_{1} \mathrm{~T}_{1}\right)$ mampu memperpanjang masa simpan dibandingkan kombinasi tanpa plastic wrapping. Dapat dilihat bahwa tidak terdapat interaksi pada setiap kombinasi perlakuan, hanya dipengaruhi oleh efek tunggal plastic wrapping.

Pengemasan dengan plastic wrapping dapat menghambat laju respirasi dan transpirasi buah. Bahan pengemas LDPE menciptakan suasana dengan tingkat $\mathrm{O}_{2}$ dan konsentrasi $\mathrm{CO}_{2}$ yang rendah sehingga mencegah pemasakan normal (Jacomino et al., 2001). Dapat diketahui bahwa plastic 
wrapping dapat digunakan sebagai perlakuan tunggal maupun kombinasi dengan AVG dan suhu simpan dalam memperpanjang masa simpan buah.

Pelunakan pada buah terjadi akibat proses repirasi selama pemasakan. Laju respirasi yang tinggi akan mempercepat pelunakan. Perlakuan AVG 1,25 ppm $\left(\mathrm{A}_{1}\right)$ tidak nyata dalam menunda pelunakan buah jambu biji 'Mutiara' (Tabel 1). Hal ini diduga karena konsentrasi AVG yang digunakan masih rendah sehingga tidak mampu menghambat biosintesis etilen yang memicu pemasakan dan buah cepat mengalami pelunakan. Pada penelitian Toan et al. (2009), aplikasi AVG 142,5 ppm pada buah pisang 'Cavendish' mampu menunda pelunakan pada buah dibandingkan kontrol.

Umumnya semakin lama disimpan, maka kulit buah semakin lunak (Sitorus et al., 2014) dan menunjukkan penurunan progresif selama pemasakan (Bashir dan Al-Goukh, 2003). Efek positif plastic wrapping dalam memperpanjang masa simpan, justru mempercepat pelunakan buah jambu biji 'Mutiara' (Tabel 1). Perlakuan plastic wrapping $\left(\mathrm{P}_{1}\right)$ secara nyata mempercepat pelunakan buah. Hal ini karena plastic wrapping mampu memperpanjang masa simpan buah sehingga buah terus mengalami kelunakan.

Pada tabel 1, penyimpanan pada suhu dingin $21,53{ }^{\circ} \mathrm{C}\left(\mathrm{T}_{1}\right)$ tidak berpengaruh nyata terhadap kekerasan. Hal inididuga karenasuhu dingin yang digunakan kurang efektif sehingga tidak mampu menekan laju respirasiyang dapat menunda pelunakan buah sehingga perlu penyimpanan suhu lebih rendah dari $21^{\circ} \mathrm{C}$. Proses hidrolisis protopektin dan pektin yang berperan dalam menjaga tingkat kekerasan buah berlangsung lebih cepat pada suhu yang lebih tinggi (Iflah, et al., 2012).

Pelunakan buah menandai terjadinya proses pemasakan selama penyimpanan. Efek tunggal AVG dan suhu dingin yang tidak nyata dalam menunda pemasakan dan pelunakan mendominasi dan meniadakan perlakuan lainnya setelah dikombinasikan. Tidak terdapat interaksi antar kombinasi perlakuan sehingga tidak mampu menunda pelunakan buah baik pada dua dan tiga kombinasi perlakuan yang secara umum menjadi tidak nyata (Tabel 1).

Transpirasi merupakan faktor biologi yang mempengaruhi susut bobot pada buah. Sebagian besar produk hortikultura terdiri atasair, maka kehilangan air (transpirasi) secara langsung dapat menurunkan susut bobot, terutama pada buah jambu biji 'Mutiara' yang memiliki kulit tipis. Kehilangan air dapat menyebabkan kehilangan bobot, penampilan kurang menarik dan tekstur yang lunak (Rachmawati, 2010).

Proses transpirasi masih berlangsung pada buah klimakterik selama penyimpanan. Pada Tabel 1, perlakuan AVG 1,25 ppm $\left(\mathrm{A}_{1}\right)$ tidak berpengaruh nyata terhadap susut bobot buah jambu biji 'Mutiara'. Hal ini didugakarena AVG hanya mempengaruhi biosintesis etilen dan tidak berpengaruh terhadap transpirasi yang menyebabkan kehilangan air sehingga buah mengalami penyusutan bobot.

Perlakuan 1 lapis plastic wrapping $\left(\mathrm{P}_{1}\right)$ mampu menekan susut bobot buah jambu biji 'Mutiara' sebesar $17,55 \%$ dari perlakuan tanpa plastic wrapping $\left(\mathrm{P}_{0}\right)$ (Tabel1). Pelapisan dengan plastic wrapping mampu menekan kehilangan air akibat perbedaan potensial air di dalam dengan di luar buah. Hal yang sama pada penelitian sebelumnya oleh Widodoet al. (2013) bahwa jambu biji 'Mutiara' yang dikemas dengan 1 lapis plastic wrapping mampu menekan susut bobot 15,10\% dibandingkan tanpa plastic wrapping.

Perlakuan suhu dingin $21,53{ }^{\circ} \mathrm{C}\left(\mathrm{T}_{1}\right)$ tidak berpengaruh nyata terhadap susut bobot buah jambu biji'Mutiara' (Tabel 1). Hal tersebut diduga karena suhu dingin hanya mempengaruhi proses respirasi dan tidak berpengaruh terhadap proses transpirasi yang dapat menyebabkan susut bobot buah. Bron et al. (2005) mengemukakan bahwa jambu biji yang disimpan 21 dan $31^{\circ} \mathrm{C}$ memiliki susut bobot yang tidak berbeda nyata. 
Pada kombinasi tanpa AVG dan plastic wrapping $\left(\mathrm{A}_{0} \mathrm{P}_{1}\right)$, AVG dan 1 lapis plastic wrapping $\left(\mathrm{A}_{1} \mathrm{P}_{1}\right)$, plastic wrapping pada suhu ruang $\left(\mathrm{P}_{1} \mathrm{~T}_{0}\right)$, dan plastic wrapping dan suhu dingin $\left(\mathrm{P}_{1} \mathrm{~T}_{1}\right)$ mampu menekan susut bobot buah dibandingkan kombinasi tanpa plastic wrapping (Tabel 1). Dapat dilihat bahwa tidak terdapat interaksi antara dua kombinasi pelakuan, hanya dipengaruhi efek tunggal plastic wrapping.

Berdasarkan Tabel 1, sama halnya seperti pada masa simpan buah, tiga kombinasi perlakuan antara AVG, plastic wrapping, dan suhu simpan secara umum idak berbeda nyata dalam menekan susut bobot jambu biji 'Mutiara' (Tabel 1). Tetapi, kombinasi perlakuan yang terdapat plastic wrapping $\left(\mathrm{A}_{0} \mathrm{P}_{1} \mathrm{~T}_{0}, \mathrm{~A}_{1} \mathrm{P}_{1} \mathrm{~T}_{0}, \mathrm{~A}_{0} \mathrm{P}_{1} \mathrm{~T}_{1}\right.$, dan $\left.\mathrm{A}_{1} \mathrm{P}_{1} \mathrm{~T}_{1}\right)$ mampu menekan susut bobot buah dibandingkan dengan kombinasi tanpa plastic wrapping. Hal tersebut menunjukkan tidak terdapat interaksi antarperlakuan, hanya dipengaruhi efek tunggal plastic wrapping. Dengan kata lain, plastic wrappingmerupakan perlakuan yang paling baik dan dapat digunakan sebagai perlakuan tunggal karena dengan atau tanpa AVG pada suhu simpan (suhu dingin dan suhu ruang) mampu menekan susut bobot buah.

Pada Tabel 2, perlakuan AVG 1,25 ppm $\left(\mathrm{A}_{1}\right)$ dan suhu dingin $21,53{ }^{\circ} \mathrm{C}\left(\mathrm{T}_{1}\right)$ tidak nyata mempengaruhi ${ }^{\circ}$ Brix pada jambu biji 'Mutiara'. Perlakuan plastic wrapping $\left(\mathrm{P}_{1}\right)$ secara nyata berpengaruh terhadap ${ }^{\circ}$ Brix. Plastic wrapping yang berbahan LDPE menghambat laju repirasi sehingga peningkatan ${ }^{\circ}$ Brix menjadi terhambat. Pengemasan berbahan Low Density Polyethylen (LDPE) pada buah jambu biji memiliki tingkat $\mathrm{O}_{2}$ dan perembesan $\mathrm{CO}_{2}$ terendah, yaitu dengan tingkat pertukaran gas terendah antara di dalam dan di luar ruangan dibandingkan dengan kemasan lainnya (Jacomino et al., 2001).

Efek dari perlakuan tunggal AVG dan suhu dingin yang tidak nyata mendominasi dan meniadakan perlakuan lainnya setelah dikombinasikan. Dapat dilihat bahwa tidak terdapat interaksi antara kombinasi dua dan tiga perlakuan sehingga secara umum ${ }^{\circ}$ Brix menjadi tidak nyata (Tabel 2).

Tabel 2. Pengaruh AVG, plastic wrapping dan suhu simpan terhadap padatan terlarut, asam bebas, dan tingkat kemanisan buah jambu biji 'Mutiara'

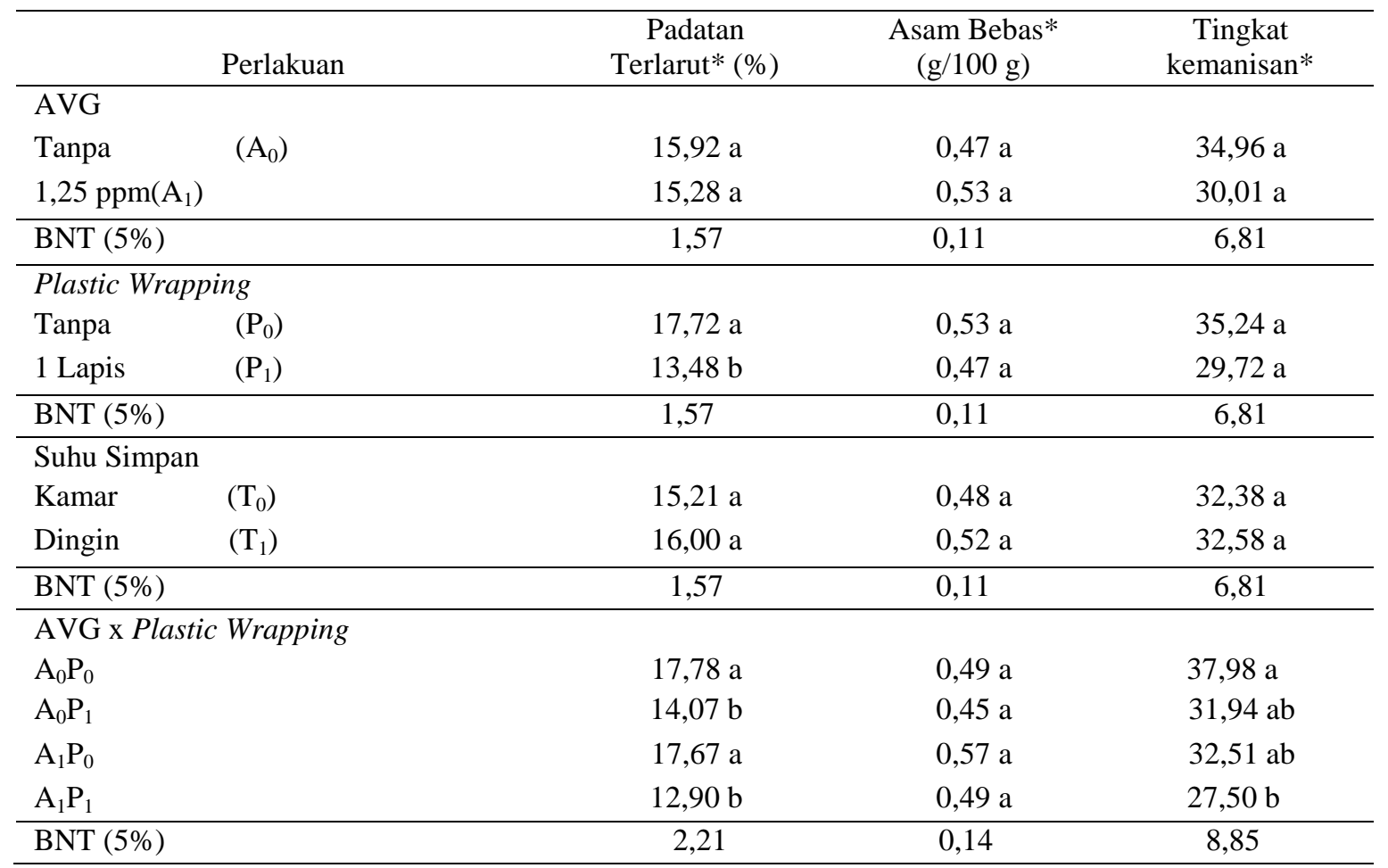




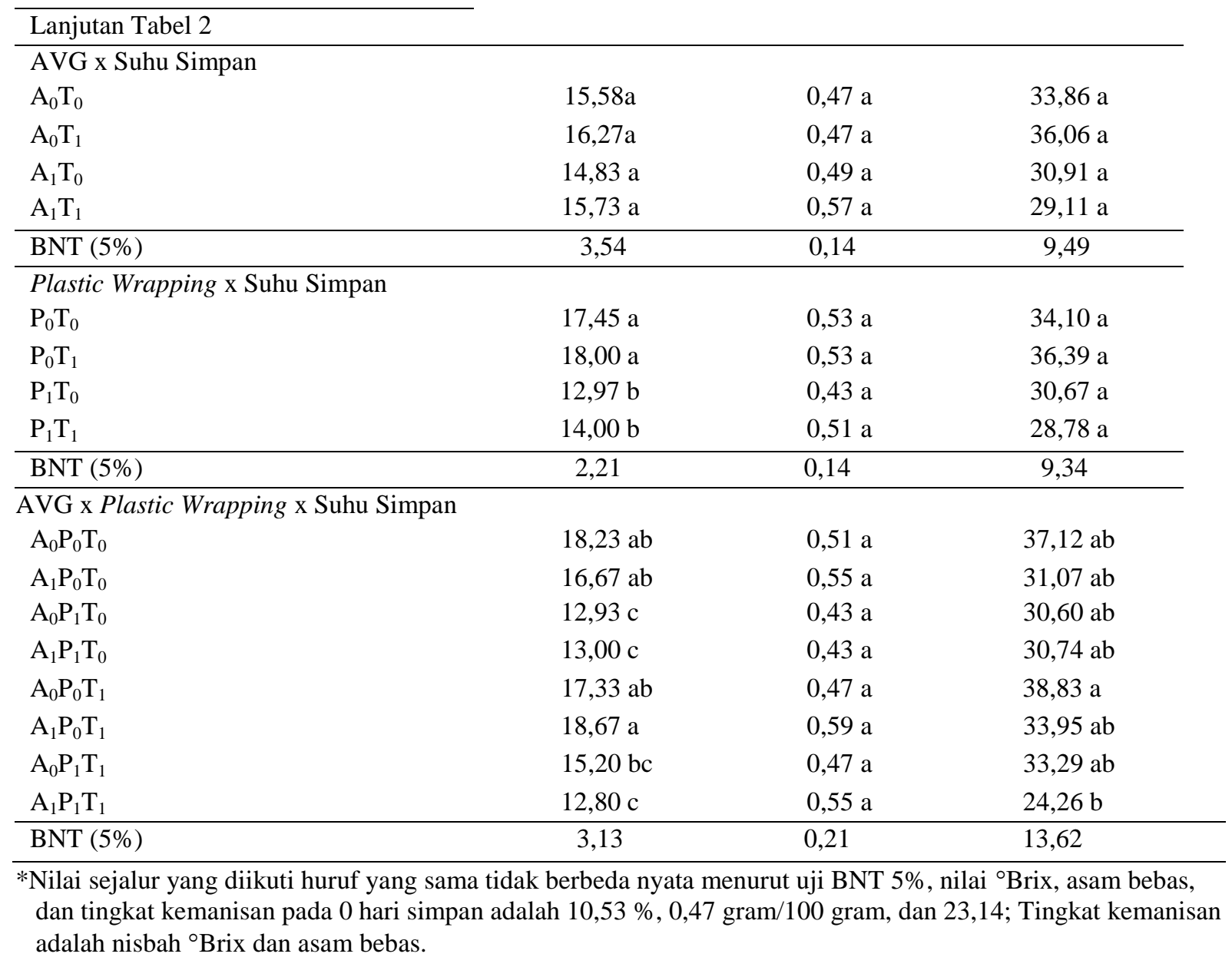

Semua perlakuan tidak nyata mempengaruhi kandungan asam bebas buah jambu biji 'Mutiara'pada awal hingga akhir pengamatan, yaitu hanya sebesar $0,47-0,59 \mathrm{~g} / 100 \mathrm{~g}$. Hal yang sama dikemukakan oleh Abreuet al. (2012) bahwa tingkat keasamaan buah jambu biji tidak berubah selama pemasakan. Asam organik yang yang dihasilkan tidak berbeda nyata diduga karena masa simpan buah dihentikan pada tingkat kemasakan dan kemerosotan mutu yang sama.

Berdasarkan Tabel 2, perlakuan AVG, plastic wrapping, dan suhu dingin umumnya tidak nyata terhadap kemanisan buah. Tetapi, kemanisan buahmengalami kenaika pada 0 hari simpan 23,14 menjadi 24,26-38,83 pada akhir pengamatan. Tingkat kemanisan buah dipengaruhi oleh kandungan padatan terlarut dan asam bebas. Peningkatan jumlah gula sejalan peningkatan total padatan terlarut dari proses respirasi yang menghidrolisis pati menjadi gula.

\section{KESIMPULAN}

1. Aplikasi AVG $1,25 \mathrm{ppm}$ dan penyimpanan pada suhu dingin $21,53{ }^{\circ} \mathrm{C}$ tidak berpengaruh nyata terhadap masa simpan, kekerasan, susut bobot, ${ }^{\circ}$ Brix, asam bebas, dan tingkat kemanisan buah jambu biji 'Mutiara'. Aplikasi plastic wrapping dapat memperpanjang masa simpan 17 hari lebih lama dibandingkan tanpa plastic wrapping dan dapat menekan susut bobot, tetapi mempercepat pelunakan dan tidak dapat mempertahankan ${ }^{\circ}$ Brix, serta tidak berpengaruh nyata terhadap asam bebas, dan tingkat kemanisan buah jambu biji 'Mutiara'. 
2. Tidak terdapat pengaruh interaksi antara AVG dengan plastic wrapping, AVG dengan suhu dingin, dan plastic wrapping dengan suhu dingin terhadap masa simpan, kekerasan, susut bobot, ${ }^{\circ}$ Brix, asam bebas, dan tingkat kemanisan buah jambu biji 'Mutiara', dan

3. Tidak terdapat pengaruh interaksi antara AVG, plastic wrapping, dan suhu dingin terhadap masa simpan, kekerasan, susut bobot, ${ }^{\circ}$ Brix, asam bebas, dan tingkat kemanisan buah jambu biji 'Mutiara'.

\section{SARAN}

Pengaplikasian AVG dan plastic wrapping perlu disesuaikan dengan penyimpanan pada suhu dingin yang lebih rendah dari $21{ }^{\circ} \mathrm{C}$ agar dapat memperpanjang masa simpan dan mempertahankan mutu buah dengan lebih maksimal.

\section{DAFTAR PUSTAKA}

Abreu, J. R. D., C. D. D. Santos, C. M. P. D. Abreu, A. C. M. Pinheiro, dan A. D. Correa. 2012. Ripening Pattern of Guava Cv. Pedro Sato. Ciência e Tecnologia de Alimentos 32(2):344350 .

Bron, I. U., R. V. Ribeiro, F. C. Cavalini, A. P. Jacomino, dan M. J. Trevisan. 2005. TemperatureRelated Changes in Respiration and $\mathrm{Q}_{10}$ Coefficient of Guava. Scientia Agricola 62(5):458463.

Bashir. H. A. dan A. B. A. Abu-Goukh. 2003. Changes in Pectic Enzymes and Cellulase Activity During Guava Fruit Ripening. Journal of Food Chemistry 83:213-218.

Capitani, G., L. Darla, Mc. Carthy, H. Gut, G. Markus, Grutter, dan J. F. Kirsch. 2002. Apple 1Aminocyclopropane-1-Carboxylate Synthase in Complex with The Inhibitor LAminoethoxyvinylglycine: Evidence for A Ketimine Intermediate. Journal of Biological Chemistry 277(51): 49735-49742.

Cline, J. A. 2006. Effect of Aminoethoxyvinylglycine and Surfactants on Preharvest Drop, Maturity, and Fruit Quality of Two Processing Peach Cultivars. Hortscience 41(2):277-383.

Iflah, T., Sutrisno, dan T. C. Sunarti. 2012. Pengaruh Kemasan Starch-Based Plastics (Bioplastik) Terhadap Mutu Tomat dan Paprika Selama Penyimpanan Dingin. Jurnal Teknologi Industri Pertanian 22 (3):189-197.

Jacomino, A. P., C. I. G. D. L. Sarantópoulos, J. M. M. Sigrist, R. A. Kluge, dan K. Minami. 2001. Sensorial Characteristics of "Kumagai" Guavas Submitted to Passive Modified Atmosphere in Plastic Packages. Journal of Plastic Film and Sheeting 17:6-21.

Rachmawati, M. 2010. Pelapisan Chitosan Pada Buah Salak Pondoh (Salacca edulis Reinw.) Sebagai Upaya Memperpanjang Umur Simpan dan Kajian Sifat Fisiknya Selama Penyimpanan. Jurnal Teknologi Pertanian 6(2):45-49.

Ruzaina, I., A. R. Norizzah, M. S. H. Zahrah, C. S. Cheow, M. S. Adi, A. W. Noorakmar, dan A. M. Zahid. 2013. Utilisation of Palm -Based and Beeswax Coating on The Postharvest-Life of Guava (Psidium guajava L.) during ambient and chilled storage. International Food Research Journal 20(1):265-274. 
Soesiladi E. Widodo Dkk, Pengaruh Aminoethoxyvinylglycine (Avg), Plastic Wrapping dan ....

Tarabih, M. E.2014. Improving Storability of Le Conte Pear Fruit Using Aminoethoxyvinylglycine (AVG) and Oxalic Acid (OA) Under Cold Storage Conditions. Asian Journal of Crop Science 6:320-333.

Toan, N. V., L. V. Hoang, L. V Tan, L. T. L. Thanh, C. D. Thanh, dan T. M. Hanh. 2009. Effects of Retain - AVG (Aminoethoxyvinylglycine) on The Storage Time of Banana (Musa Cavendish AAA) After Harvest. Tap Chi Khoa Hoc Va Cong Nghe Tap 47 (1):27-33.

Widodo, S. E., Zulferiyeni, dan R. Arista. 2013. Coating Effect of Chitosan and Plastic Wrapping on The Shelf-Life and Qualities of 'Mutiara' And 'Crystal' Guavas. J.ISSAAS 19(1):1-7. 